\title{
PROCESSING MISSING POWER DATA IN WIRELESS SENSOR NETWORKS
}

\author{
Yonglin Liang, Jingguo Dai
}

Original scientific paper

The application prospects of wireless sensor networks (WSN) are very broad due to their characteristics of convenience, low cost, accuracy. Wireless sensor networks have potential applications in many fields, such as business, smart home appliances, industry. Wireless sensor networks are considered to be one of the most influential technologies today. The power industry is not only related to the livelihood of individuals, but also to national security. At present, the development of the power industry has reached a bottleneck. One of the methods to break through the bottleneck of the development of the electric power industry is by combining the wireless sensor networks with the electric power industry and building a smart grid. Due to various reasons, the data generated by the wireless sensor networks may be lost, and the missing data will have a great impact on the detection of power data and the construction of the smart grid. The power data generated by the wireless sensor networks has both temporality and spatiality. In this paper, we propose a fusion algorithm to deal with the missing data in wireless sensor networks. Experimental results show that the proposed algorithm can effectively estimate the missing power data in wireless sensor networks.

Keywords: fusion method; missing data; smart grid; wireless sensor networks

\section{Obrada nedostajućih podataka o energiji u bežičnim senzorskim mrežama}

Izvorni znanstveni članak Izgledi za primjenom bežičnih senzorskih mreža - wireless sensor networks (WSN) vrlo su veliki zbog njihovih karakteristika - praktičnosti, niske cijene točnosti. Moguće ih je primijeniti u mnogim područjima kao što su poslovanje, inteligentni kućni uređaji, industrija. Smatra ih se jednom od najutjecajnijih tehnologija danas. Električna energija se ne odnosi samo na zaradu za život pojedinaca već i na nacionalnu sigurnost. Trenutno je razvoj energetske industrije stigao do uskog grla. Jedna od metoda za razbijanje uskog grla u razvoju energetike je kombiniranje bežičnih senzorskih mreža s elektroindustrijom i izgradnja inteligentne mreže. Zbog raznih se razloga mogu izgubiti podaci koje generiraju bežične senzorske mreže i ti će nestal podaci imati veliki utjecaj na pronalaženje podataka o energiji i izgradnju inteligentne mreže. Podaci o energiji koje generiraju bežične senzorske mreže imaju i temporalnost i prostornost. U ovom radu predlažemo fuzijski algoritam koji se bavi podacima koji nedostaju u bežičnim senzorskim mrežama. Eksperimentalni podaci pokazuju da se predloženim algoritmom mogu učinkovito procijeniti podaci o energiji koji nedostaju u bežičnim senzorskim mrežama.

Kljućne riječi: bežične senzorske mreža; inteligentna mreža; metoda fuzije; nedostajući podaci

\section{Introduction}

In the twenty-first century, all aspects of society put higher and higher requirements on the power system with the overall recovery of the global economy. The power system must meet the needs of users and also have high security, diversification and other features to meet various challenges [1]. At present, the power system is facing the challenges of environmental protection, flexibility, reliability, etc. The best way to solve these problems is by combining a wireless sensor network with the power grid to build a smart grid. Once the concept of smart grid has been proposed, it has attracted much attention globally [2, 3].

Table 1 Power data classification

\begin{tabular}{|c|c|c|}
\hline $\begin{array}{c}\text { Monitoring data of } \\
\text { power network } \\
\text { operation }\end{array}$ & $\begin{array}{c}\text { Power enterprise } \\
\text { operational data }\end{array}$ & $\begin{array}{c}\text { Power enterprise } \\
\text { management data }\end{array}$ \\
\hline $\begin{array}{c}\text { Generation } \\
\text { capacity, voltage, } \\
\text { reserve capacity, } \\
\text { voltage stability }\end{array}$ & $\begin{array}{c}\text { Transaction price, } \\
\text { electricity } \\
\text { consumption, user } \\
\text { data, pollutant } \\
\text { emissions, etc. }\end{array}$ & $\begin{array}{c}\text { ERP, integrated } \\
\text { platform, } \\
\text { cooperative office }\end{array}$ \\
\hline
\end{tabular}

At present, the power system has been deployed throughout China [4]. The transmission network and distribution network send power to millions of households. In order to reasonably adjust the allocation of power resources, we must be aware of the power data in a timely manner to use the power resources more effectively [5]. By collecting relevant data, wireless sensor networks can provide more comprehensive network operation data for the relevant managers. At the same time, managers can also analyze the power data, monitor the smart grid equipment, and rapidly construct the data communication network [6]. These will be the key technologies to solve the above problems in the smart grid. The emergence of wireless sensor networks provides a new prospect for the development of the smart grid. The power data classification is shown in Tab. 1.

The use of power data is bidirectional [7]. The electric power enterprise can collect user data through the power point data to make related analysis and provide the basis for adjustments in transportation planning for electric power development. Furthermore, power users can study the household electricity. At the same time, the user can combine the wireless sensor networks with household appliances to control the electricity consumption of their household appliances timely and accurately. These methods can further realize intelligent home furnishing and achieve safety, high efficiency and economic power standard [8]. The system structure of WSN for the smart grid is shown in Fig. 1.

One development trend in the electric power industry is to acquire power data and build a smart grid through wireless sensor networks [9]. The power data acquired by the wireless sensor networks has the characteristics of temporality and spatiality. There is a certain data loss phenomenon in the process of data acquisition from the wireless sensor to the terminal. Estimating these lost power data can reduce loss which is caused by the loss of power data [10]. 


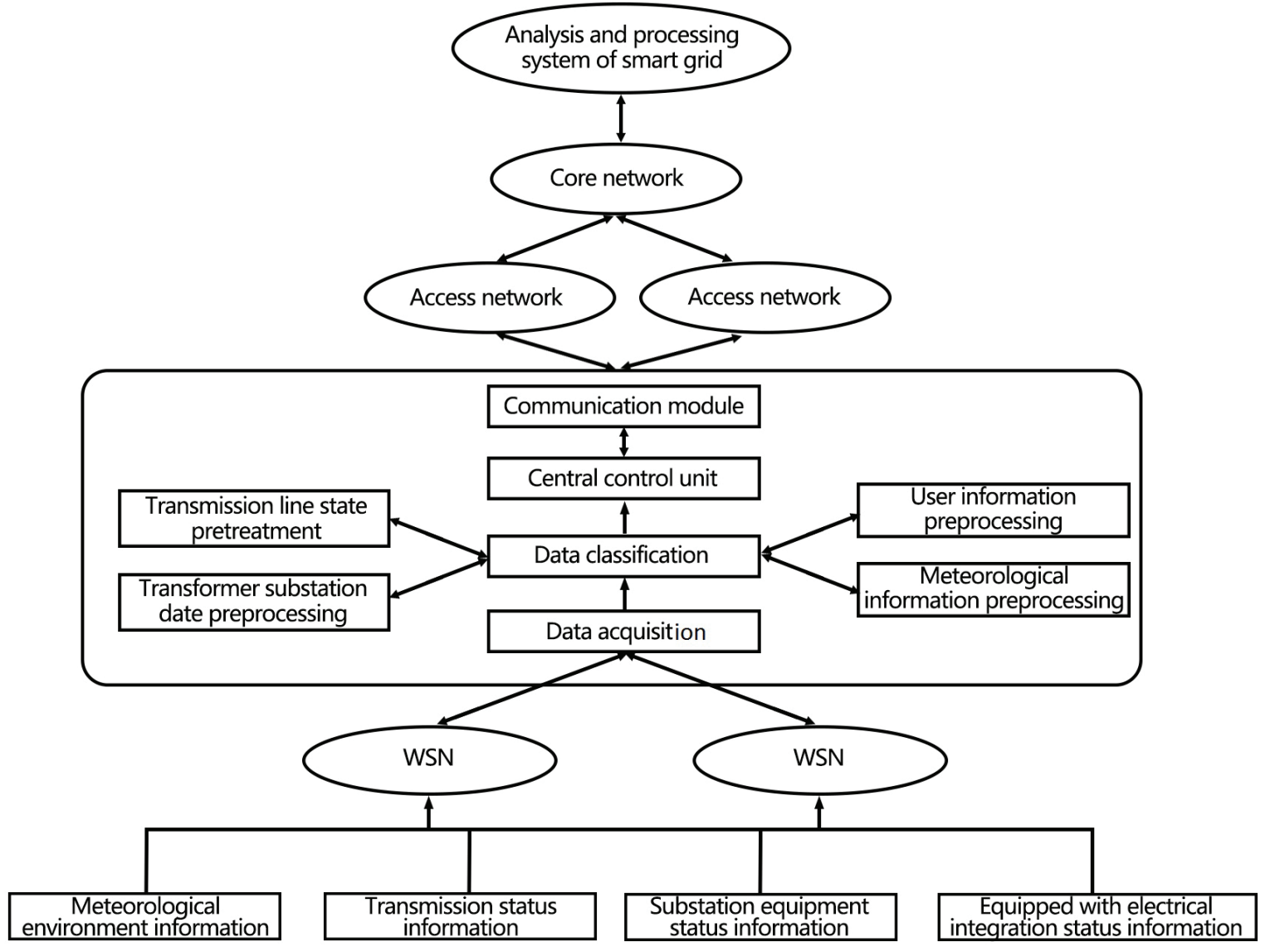

Figure 1 System structure of WSN for smart grid

This paper proposes a fusion algorithm to estimate the lost power data. This algorithm estimates the lost power data from the angle of temporality and spatiality. Then, the results are fused, resulting in a more accurate estimate. The first part of this paper is the introduction, where we introduce the research background. The second part describes the application of wireless sensor networks in the power system and the characteristics of power network data. The third part proposes the fusion algorithm which considers the lost power data of temporal and spatial characteristics.

\section{Application of the wireless sensor networks in a power system and characteristics of power network data}

Wireless sensor networks are composed of a set of nodes with embedded processors, sensors and wireless transceivers. The application of wireless sensor networks in the power industry involves the production, transmission and use of electric energy. These constitute a complex, dynamic process [11]. The typical network architecture of WSN is shown in Fig. 2.

Electricity must be transported through large and complex power generation, transmission and distribution facilities [12]. Therefore, any fault in the power grid may result in a series of accidents, which may lead to the collapse of the power grid, would bring huge losses to the country and individuals. During the operation of the power network, wireless sensor networks are used to monitor the operation of the power grid. The expansion of the scale of the power grid and the increase in demand for electricity promote the improvement of the operation and management level of the power grid [13]. The difference between the smart grid and the traditional power grid is shown in Fig. 3.

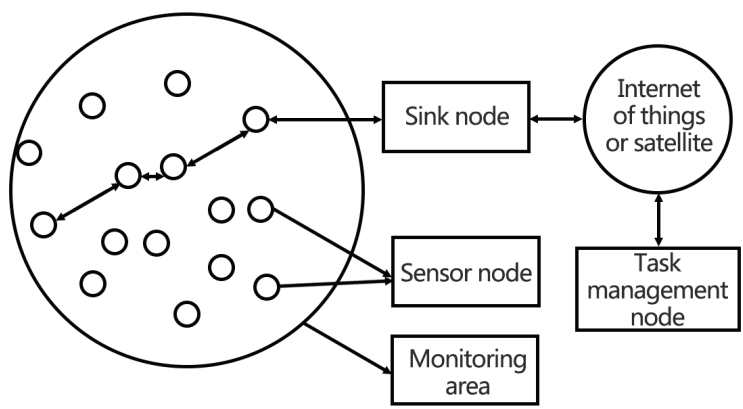

Figure 2 Typical network architecture of WSN

We use wireless sensor networks to capture these power data. The data captured by the wireless sensor networks play an important role in the scientific planning and construction, system operation, automatic control, etc. The construction and development of the smart grid not only depends on intelligent power equipment, but also depends on the collection, transmission, transformation, distribution, use and adjustment of the whole network. With the wide application of digital devices, the data generation process is passive, active and automatic. The smart grid operation monitoring data sources are shown in Tab. 2. 

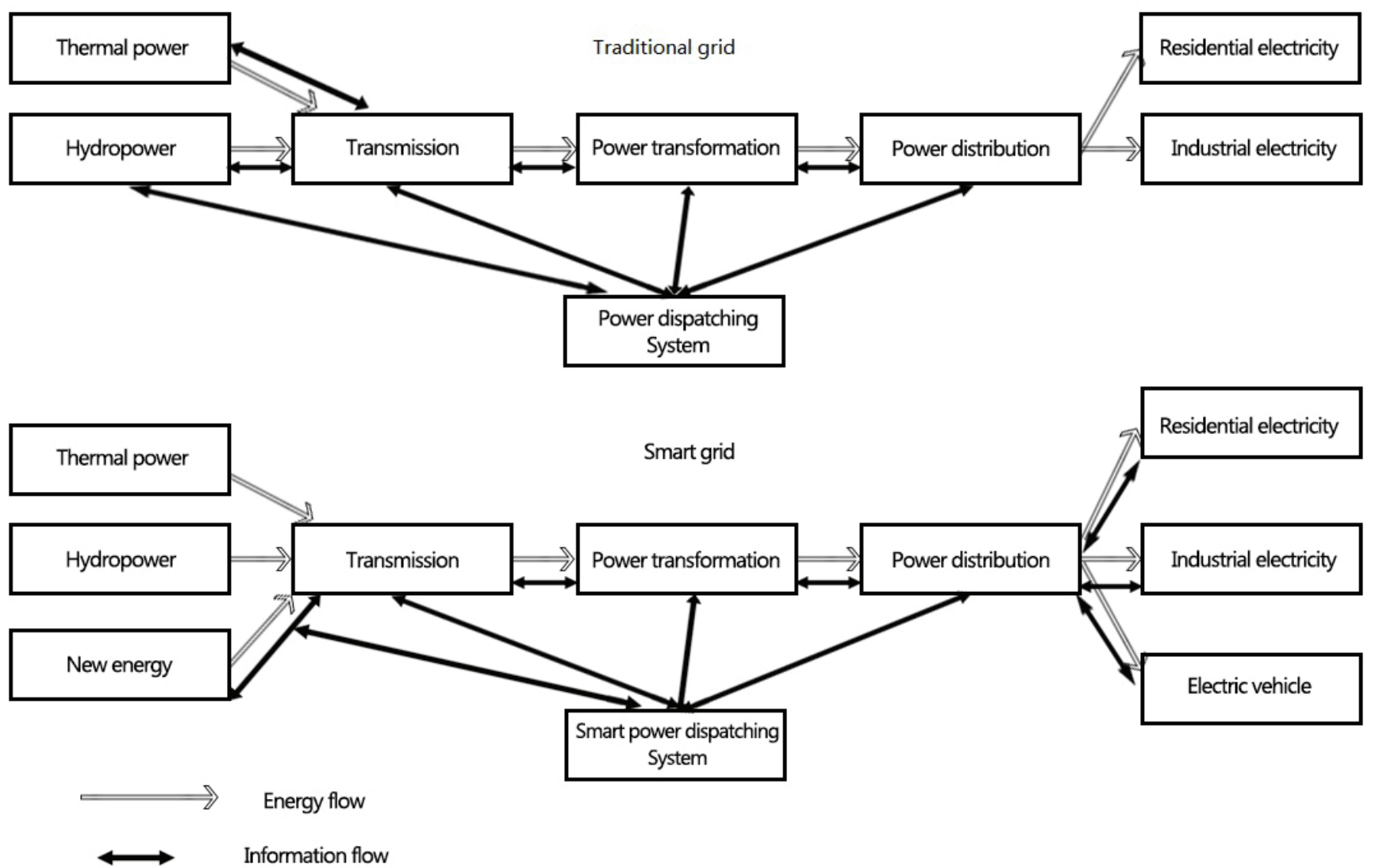

Figure 3 Difference between smart grid and traditional power grid

Table 2 Smart grid operation monitoring data sources

\begin{tabular}{|c|c|c|c|c|}
\hline System & Subsystem & Equipment & Application & Characteristics \\
\hline \multirow{2}{*}{$\begin{array}{c}\text { Power system operation and } \\
\text { maintenance measurement } \\
\text { system }\end{array}$} & SCADA & RTU & Adjustable electricity & Low frequency, not practical \\
\cline { 2 - 5 } & WAMS & PMU & Transmission & $\begin{array}{c}\text { Phase measurement, GPS timing, } \\
\text { accuracy and high frequency }\end{array}$ \\
\cline { 2 - 5 } & SAS & IED & Distribution & $\begin{array}{c}\text { Real time, integrated } \\
\text { measurement and control }\end{array}$ \\
\hline $\begin{array}{c}\text { Personal user measurement } \\
\text { system }\end{array}$ & AMI & Smart Meter & $\begin{array}{c}\text { Distribution and utilization of } \\
\text { electricity }\end{array}$ & $\begin{array}{c}\text { Two-way communication, high } \\
\text { frequency, automatic recording }\end{array}$ \\
\hline
\end{tabular}

Wireless sensor networks technology is one of the hotspots of smart grid research (14). Compared with the traditional wired network, wireless sensor network has the characteristics of low cost, fast deployment and it ensures the same level of fault tolerance as the wired networks (15). Wireless sensor networks can complete the fast construction of the data communication network for the diagnosis, monitoring and power statistics of the smart grid equipment (16). The basic idea of applying the wireless sensor networks to the smart grid is to realize the bidirectional flow of data in the grid and to monitor the operation of the key equipment of the sensor in real time (17).

Wireless sensor networks have limited communication capabilities. In the power system test or the specific production operation, an obstruction may cause a temporary disconnection of the link, or data packet dropout in the process of data transmission [18]. For example, when the node capacity is exhausted, nodes cannot capture the power data and the data stored in the node cannot return in a timely manner. In addition, the artificial reason will also cause the destruction of the node. These all contribute to the lack of data. Wireless sensor networks missing data is inevitable. These missing data will affect the results of the data analysis, resulting in the loss of power grid operation. In order to solve this problem, we need to deal with missing data. We must estimate the missing data and fill the gaps of the missing values with the estimated values.

\section{Fusion method}

Firstly, we propose a temporality data processing method.

The data set is $T=\left\{\left(x_{1}, y_{1}\right),\left(x_{2}, y_{2}\right), \cdots,\left(x_{n}, y_{n}\right)\right\} \cdot x_{i}$ is the input variable and $y_{i}$ is the output variable. $x_{i} \in R^{d}$ is the in-out value of the $i$ training sample and $d$ dimensional vector. $y_{i} \in R$ is the corresponding target value. Nonlinear support vector regression solves the function:

$y=f(x)=w^{T} \phi(x)+b$

where $w$ is regression function and $\phi(x)$ is mapping function, $b$ is threshold. The input variable $x_{i}$ in training sample $T$ is the support vector. $\varepsilon$ is the insensitivity 
coefficient. Any insensitive function $\varepsilon>0$ if the hyperplane $\varepsilon$ contains all the data points in the training set. Hyperplane $y=f(x)$ satisfies:

$-\varepsilon \leq y-w^{T} \phi\left(x_{i}\right)-b \leq \varepsilon$

The distance between any data point $\left(\phi\left(x_{i}\right), y_{i}\right) \in T$ in training sample $T$ and the hyperplane is:

$d_{i}=\frac{\left|{ }^{T} \phi\left(x_{i}\right)+b-y_{i}\right|}{\sqrt{1+\|w\|^{2}}} \leq \frac{\varepsilon}{\sqrt{1+\|w\|^{2}}}$

$\frac{\varepsilon}{\sqrt{1+\|w\|^{2}}}$ is the upper limit of the distance between the data point in training sample $T$ and hyperplane.

The problem is further transformed into:

$$
\begin{aligned}
& \min \frac{1}{2}\|w\|^{2}+C \sum_{i=1}^{n}\left(\xi_{i}+\xi_{i}^{*}\right) \\
& \text { s.t. }\left\{\begin{array}{l}
-\varepsilon \leq y_{i}-<w^{T} \phi\left(x_{i}\right)>-b \leq \varepsilon+\xi_{i} \\
<w^{T} \phi\left(x_{i}\right)>+b-y_{i} \leq \varepsilon+\xi_{i}^{*}
\end{array}\right.
\end{aligned}
$$

$C$ is the penalty factor. The problem of support vector regression can be solved by solving the above optimization problem, thus obtaining $w$ and $b$.

The optimization problem is transformed into:

$$
\begin{aligned}
& \min _{w, b, e} Q(w, B, e)=\frac{1}{2}\|w\|^{2}+\frac{1}{2} \gamma \sum_{i=1}^{n} e_{i}^{2} \\
& \text { s.t. } e_{i}=y_{i}-w^{T} \phi\left(x_{i}\right)+b
\end{aligned}
$$

where $w^{T} \phi\left(x_{i}\right)+b$ is the hyperplane in high dimensional feature space, $w$ and $b$ are the parameters of the hyperplane, $e_{i}$ is the training error of $i$ training data point, $\sum_{i=1}^{n} e_{i}^{2}$ is empirical risk. $\gamma>0$ is the regularization parameter which balances the complexity of the machine learning process and the empirical risk. According to the theory of constrained optimization, the Lagrange function of the optimization problem is:

$$
L(w, b, e ; \alpha)=J(w, e)-\sum_{i=1}^{N} \alpha_{i}\left\{w^{T} \varphi\left(x_{i}\right)+b+e_{i}-y_{i}\right\}
$$

We can obtain:

$$
\begin{aligned}
& b=\frac{\overline{1}^{T} A^{-1} y}{\overline{1}^{T} A^{-1} \overline{1}} \\
& a=A^{-1}(y-b \overline{1})
\end{aligned}
$$

And the regression function is:

$$
f(x)=\sum_{i=1}^{N} \alpha_{i} K\left(x_{i}, x_{j}\right)+b
$$

In the training process of modeling, we analyze the $n$ training input sensor data and take out the $k(k<n)$ historical sensor data variables that are most relevant to the current estimate. We set $k$ sensor data variables as the input value of LSSVR to reduce the computational complexity in the process of training modeling. This can greatly improve the efficiency of the estimation method. The framework sensor data estimation method is shown in Fig. 4.

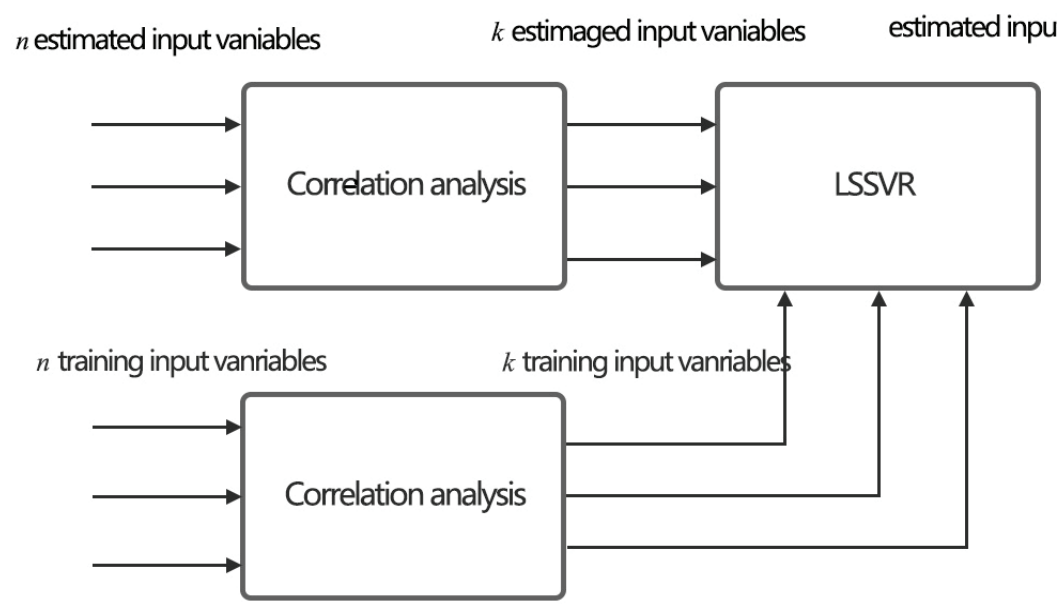

Figure 4 Framework of sensor data estimation method

After correlation analysis is processed, the $n$ dimension sensing data set is reduced approximately to the $k$ dimension of the training input data set, thus reducing the computational complexity of training.

$\min _{w, b, e} Q(w, B, e)=\frac{1}{2}\|w\|^{2}+\frac{1}{2} \gamma \sum_{i=1}^{n} e_{i}^{2}$
Next, we propose a spatial data processing method.

Voronoi can be used as the segmentation method of sensor nodes. Voronoi treats the value of sensor node as the result of the joint action of natural neighbor nodes.

We use $E^{d}\left(R^{d}\right)$ to indicate $d$ dimensional Euclidean space.

Definition $1 p$ is a point. $p$ in $E^{d}$ is defined as a $d$ tuple. $p$ can be expressed as a vector which has $d$ weights. 
The starting point of the vector is the origin of coordinates. The terminal point is $p$.

Definition $2 p_{1}$ and $p_{2}$ are in $E^{d}$. The linear combination $\alpha p_{1}+(1-\alpha) p_{2}$ is a line in $E^{d}$. If there are $k$ linear independent points $p_{1}, p_{2}, \ldots, p_{k}$, the linear combination

$$
\alpha_{1} p_{1}+\alpha_{2} p_{2}+\alpha_{k-1} p_{-1}+\left(1-\alpha_{1}-\cdots, \alpha_{-1}\right) p_{k}
$$

is the $k-1$ dimensional linear cluster in $E^{d}$.

Definition 3 There are two points $p_{1}$ and $p_{2}$ in $E^{d}, \alpha p_{1}+(1-\alpha) p_{2}$ is a line segment in $E^{d}$.

Definition $4 D$ is the domain in $E^{d} \cdot p_{1}$ and $p_{2}$ are any two points in $D$. If the line segment $\overline{p_{1} p_{2}}$ is completely contained in $D$, the domain is convex.

We set $P=\left(p_{1}, p_{2}, \ldots, p_{n}\right), p_{i} \neq p_{j}, p_{i}, p_{j}$. The vertical bisector of the line (hyperplane) divides the space (hyperspace) into two halves. $H_{i}\left(p_{i}, p_{j}\right)$ is the half space of $p_{i}$ and $p_{j}$ on one side.

$$
\begin{aligned}
V\left(p_{i}\right) & =\left\{x \mid\left\|x-p_{i}\right\| \leq\left\|x-p_{j}\right\|\right\} \\
& =\bigcap_{j \in I_{n} /\{i\}} H\left(p_{i}, p_{j}\right)
\end{aligned}
$$

$V\left(p_{i}\right)$ is called the $m$ dimensional Voronoi polyhedron about $p_{i}$.

$$
\gamma(p)=\left\{V\left(p_{i}\right), \cdots, V\left(p_{n}\right)\right\}
$$

$\gamma(p)$ is called $m$ dimensional Voronoi figure which is generated by point set $p$.

We call the point $p_{i}$ in Voronoi Polygon $V\left(p_{i}\right)$ the generator point of $i$ Voronoi Polygon $V\left(p_{i}\right)$. It also is called kernel. Point set $P=\left(p_{1}, p_{2}, \ldots, p_{n}\right)$ is the generator set of $\gamma(p)=\left\{V\left(p_{i}\right), \ldots, V\left(p_{n}\right)\right\}$.

In the actual calculation, we use Voronoi partition twice. For the first time, we divide the sensor node distribution space according to the sensor nodes. Then we calculate the contribution of natural neighbor nodes by inserting Voronoi, namely the proportion of the two order Voronoi diagram. We consider the distance of each natural neighboring node from the missing node. Lastly, the normalized and weighted average is used to estimate the missing values.

Step 1: The two order Voronoi diagram is generated by the location of the $N$ sensor nodes and the observed values of the nodes of the sensor nodes.

Step 2: Calculate the area of a polygon $A(x)$ according to the first order Voronoi observation point.

Step 3: Calculate the overlap area $A_{i}(x)$ of the observed value missing point and the natural neighboring node. Then we normalize and get:

$w_{1 i}(x)=\frac{A_{i}(x)}{A(x)}$

Step 4: $b_{i}(x)$ is the length of the edge of the natural neighboring node according to the observed value missing point of the Voronoi polygon. $h_{i}(x)$ is the distance between the node $x$ and the natural neighboring node $i$. $\omega_{j}(x)=\frac{b_{i}(x)}{h_{i}(x)}$

Then we normalize and get:

$\omega_{2 i}(x)=\frac{\omega_{i}(x)}{\sum_{j} \omega_{j}(x)}$

Step 5: Calculate the weighted interpolation coefficient of the natural neighbor node as follows:

$w_{i}(x)=\frac{1}{2}\left[w_{1 i}(x)+w_{2 i}(x)\right]$

Step 6: Estimate the missing values as follows:

$\tilde{y}_{2}=\sum_{j=1}^{k} w_{i} \cdot y_{2}$

For the missing value at $t$ time, we use time methods to get the estimated value. Then, we get the weighted mean.

We suppose that the missing value $\frac{\theta_{1 t}}{y_{1}}$ is obtained by the first method and $\frac{y_{2 t}}{2}$ by the second method. The missing value is:

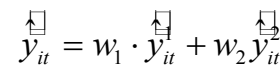

where $w_{1}$ and $w_{2}$ are weight coefficients, $y_{i t}$ and $y_{i t}$ are the estimated values of the missing data. Therefore, we should give more weight to more accurate estimates intuitively. We consider that the sample determination coefficient $R^{2}\left(0 \leq R^{2} \leq 1\right)$ shows the fitting degree of the regression equation and sample data. Obviously, the regression equation fits the sample data better, and the estimated value is more accurate. Therefore, we can define the weight by the sample decision coefficient:

$R^{2}=\frac{\sum_{k=1}^{h}\left(\hat{y}_{i k}-\hat{y}_{i}\right)^{2}}{\sum_{k=1}^{h}\left(y_{i k}-\hat{y}_{i}\right)^{2}}$

where $\hat{y}_{i}$ is the sample mean value of missing node. We can determine that $R^{2}$ is related to the number of explanatory variables and the sample size. With the increase in the number of explanatory variables and the sample size, $R^{2}$ will increase. Therefore, in order to eliminate the influence of the number of explanatory variables on $R^{2}$, the fusion algorithm uses the adjusted coefficient of determination to define the weight:

$\bar{R}^{2}=1-\left(1-R^{2}\right) \frac{h-1}{h-k-1}$

where $h$ is sample size, $k$ is the number of explanatory variables in the regression equation. 
Adjusted coefficients of determination are:

$$
\begin{aligned}
& w_{1}=\frac{\bar{R}_{1}^{2}}{\bar{R}_{1}^{2}+\bar{R}_{2}^{2}} \\
& w_{2}=\frac{\bar{R}_{2}^{2}}{\bar{R}_{1}^{2}+\bar{R}_{2}^{2}}
\end{aligned}
$$

\section{Experiment}

In this paper, we select the complete data set for the experiment in order to verify the validity and accuracy of the fusion algorithm. We assume that some data are missing. The results are compared with the real values. The relationship between RMSE and the sampling interval is shown in Fig. 5.

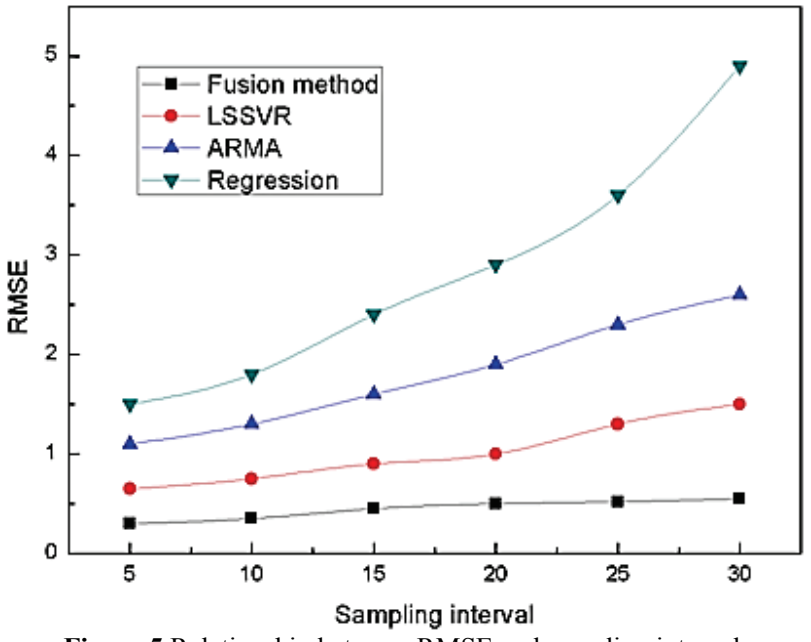

Figure 5 Relationship between RMSE and sampling interval

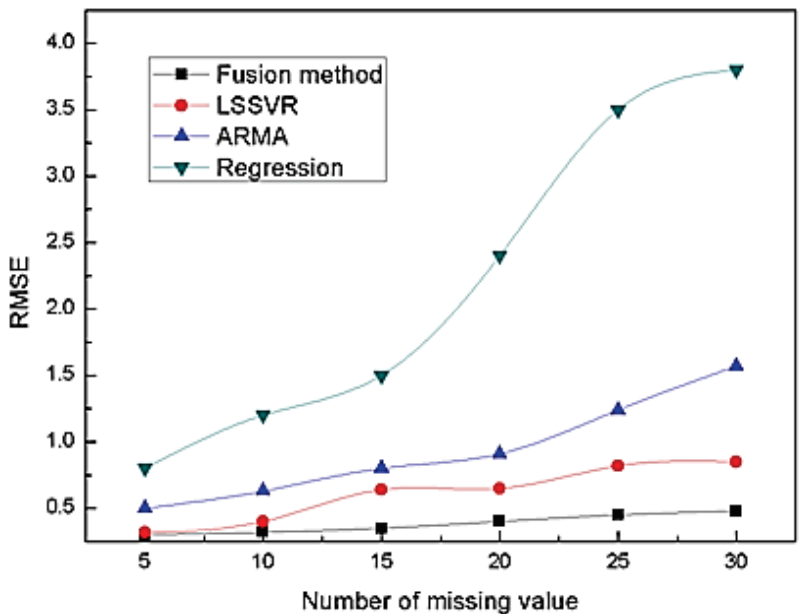

Figure 6 Relationship between RMSE and the number of missing values

Fig. 5 shows that with the increase in the sampling interval of the perceptual data, the estimation error of the missing values increases gradually. When the sampling interval of the sensing data increases, the temporal correlation of the sensing data decreases, which leads to an increase in the estimation error.

The relationship between RMSE and the number of missing values is shown in Fig. 6 .
With the increase in the number of missing data, the estimation error increases. The correlation between the number of missing values and the known data is then reduced. This leads to an increase in the estimation error.

Figs. 5 and 6 show that the fusion algorithm proposed in this paper is the most accurate compared with other methods. The RMSE of the fusion algorithm is minimal. This fully demonstrates the effectiveness and superiority of the fusion algorithm.

\section{Conclusions}

The power industry is constantly producing huge amounts of complex data. In the operation of the power grid, the data generated in the generation, transmission, substation use, distribution, all use other links. The operation of the electric power system needs the crosssectional and cross-regional real-time interaction power information. It is supported by strong data analysis capability and data transmission. At present, the application of wireless sensor networks in the power network for data acquisition and transmission is the mainstream of the current development. However, the lack of power data is an inevitable problem. Missing data will affect the normal operation of the power industry and decision making. In this paper, we propose a fusion algorithm to deal with the problem of missing data in wireless sensor networks. The main work of this paper includes, (1) introducing the background of the article , (2) introducing the application of wireless sensor networks in the grid, (3) introducing the LSSVR and Voronoi and proposing a fusion algorithm to deal with the missing wireless sensor networks power data, (4) the experiment that verifies the validity and accuracy of this method

\section{Acknowledgements}

Our work is supported by the National nature science foundation of China (under Grants No. 61462019) and the construction funds of the fourth group of key discipline by Shaoguan University.

The authors would like to recognize the others who helped them and thank all our reviewers.

\section{References}

[1] Fichter, T.; Soria, R.; Szklo, A.; Schaeffer, R.; Lucena, A. F. P. Assessing the potential role of concentrated solar power (CSP) for the northeast power system of Brazil using a detailed power system model. // Energy. 121, (2017), pp. 695-715. https://doi.org/10.1016/j.energy.2017.01.012

[2] Lee, A. H. I.; Chen, H. H.; Chen, J. Building smart grid to power the next century in Taiwan. // Renewable and Sustainable Energy Reviews. 68, (2017), pp. 126-135. https://doi.org/10.1016/j.rser.2016.09.100

[3] Irfan, M.; Iqbal, J.; Iqbal, A.; Iqbal, Z.; Mehmood, A. Opportunities and challenges in control of smart grids Pakistani perspective. // Renewable and Sustainable Energy Reviews. 71, (2017), pp. 652-674. https://doi.org/10.1016/j.rser.2016.12.095

[4] Pingkuo, Liu; Zhongfu, Tan. How to develop distributed generation in China: In the context of the reformation of electric power system. // Renewable and Sustainable Energy Reviews. 66, (2016), pp. 10-26. 
https://doi.org/10.1016/j.rser.2016.07.055

[5] Masnicki, R.; Mindykowski, J. Coordination of operations in registration channel of data from electrical power system. // Measurement. 99, (2017), pp. 68-77. https://doi.org/10.1016/j.measurement.2016.12.013

[6] Roeber, J. B. W.; Pitla, S. K.; Kocher, M. F.; Luck, J. D.; Hoy, R. M. Tractor hydraulic power data acquisition system. // Computers and Electronics in Agriculture. 127, (2016), pp. 1-14. https://doi.org/10.1016/j.compag.2016.05.012

[7] Guo, Sisi; Liu, Pei; Li, Zheng. Data reconciliation for the overall thermal system of a steam turbine power plant. // Applied Energy. 165, (2016), pp. 1037-1051. https://doi.org/10.1016/j.apenergy.2016.01.002

[8] Risteska Stojkoska, B. L.; Trivodaliev, K. V. A review of Internet of Things for smart home: Challenges and solutions. // Journal of Cleaner Production. 140, 13(2017), pp. 1454-1464. https://doi.org/10.1016/j.jclepro.2016.10.006

[9] Falahati, Saber; Taher, Seyed Abbas; Shahidehpour, Mohammad. A new smart charging method for EVs for frequency control of smart grid. // International Journal of Electrical Power \& Energy Systems. 83, (2016), pp. 458469. https://doi.org/10.1016/j.ijepes.2016.04.039

[10] Emmanuel, M.; Rayudu, R. Communication technologies for smart grid applications: A survey. // Journal of Network and Computer Applications. 74, (2016), pp. 133-148. https://doi.org/10.1016/j.jnca.2016.08.012

[11] Kabashkin, I.; Kundler, J. Reliability of Sensor Nodes in Wireless Sensor Networks of Cyber Physical Systems. // Procedia Computer Science. 104, (2017), pp. 380-384. https://doi.org/10.1016/j.procs.2017.01.149

[12] Li, Yong; Yang, Jie; Song, Jian. Nano energy system model and nanoscale effect of graphene battery in renewable energy electric vehicle. // Renewable and Sustainable Energy Reviews. 69, (2017), pp. 652-663. https://doi.org/10.1016/j.rser.2016.11.118

[13] Xie, Shanshan; Sun, Fengchun; He, Hongwen; Peng, Jiankun. Plug-In Hybrid Electric Bus Energy Management Based on Dynamic Programming. // Energy Proceeding. 104, (2016), pp. 378-383. https://doi.org/10.1016/j.egypro.2016.12.064

[14] Casey, P. R.; Jaber, N. Design and Implementation of a Cross-Platform Sensor Network for Smart Grid Transmission Line Monitoring. // Getting practical-Field trials, Deployments, and lessons Learnt (IEEE Smart Grid Comm). 47, 10(2011), pp. 285-290. https://doi.org/10.1109/smartgridcomm.2011.6102334

[15] Zheng, Guilin; Gao, Yichuan; Wang, Lijuan. Realization of Automatic Meter Reading System Based on Zig Bee with Improved Routing Protocol. // Proceeding of Power and Energy Engineering Conference, 2010, pp. 28-31.

[16] Li, Wenzhong; Chan, E.; Hamdi, M.; Lu, Sanglu; Chen, Daoxu. Communication Cost Minimization in Wireless Sensor and Actor Networks for Road Surveillance. // IEEE Transactions on Vehicular Technology. 60, 2(2011), pp. 618-631. https://doi.org/10.1109/TVT.2010.2094631

[17] Cobo, L.; Quintero, A.; Pierre, S. Ant-based routing for wireless multimedia sensor networks using multiple Qo S metrics. // Computer Netwroks. 54, 17(2010), pp. 29913010. https://doi.org/10.1016/j.comnet.2010.05.014

[18] Jurado, S.; Nebot, À.; Mugica, F.; Mihaylov, M. Fuzzy inductive reasoning forecasting strategies able to cope with missing data: A smart grid application. // Applied Soft Computing. 51, (2017), pp. 225-238.

https://doi.org/10.1016/j.asoc.2016.11.040

\section{Authors' addresses}

Yonglin Liang, MSc,

College of Information Science and Engineering, Shaoguan University,

Daxue Street, Zhenjiang District,

Shaoguan city, Guangdong province, China

liangyonglin@126.com

Jingguo Dai, MSc, Prof.

College of Information Science and Engineering, Shaoguan University,

Daxue Street, Zhenjiang District,

Shaoguan city, Guangdong province, China 